Gut, 1986, 27, 73-77

\title{
Direct and antibody dependent cell mediated cytotoxicity against Giardia lamblia by splenic and intestinal lymphoid cells in mice
}

\author{
S S KANWAR, N K GANGULY, B N S WALIA, AND R C MAHAJAN \\ From the Departments of Parasitology and Paediatrics, Postgraduate Institute of Medical Education and \\ Research, Chandigarh, India
}

SUMMARY Direct cytotoxicity and antibody dependent cell mediated cytotoxicity against Giardia lamblia trophozoites exhibited by splenic, intraepithelial and lamina propria lymphocyte populations isolated from $G$ lamblia infected mice were studied. Different patterns of cytotoxicity were found. Intraepithelial lymphocytes showed a direct cytotoxic activity of $20.6 \pm 5.6 \%$ before infection. It was significantly higher on the 20th $(\mathrm{p}<0.01)$ and 30 th $(\mathrm{p}<0.05)$ day postinfection. Lamina propria lymphocytes showed a significantly augmented level of both direct cytotoxicity and antibody dependent cell mediated cytotoxicity on the 20th and 30th postinfection days. Direct cytotoxicity by splenic lymphocytes remained unchanged during infection but antibody dependent cell mediated cytotoxicity was significantly increased.

The host response to $G$ lamblia involves the immune system. Previous exposure to this infection is known to increase resistance to a second challenge in both man and animals. ${ }^{12}$ Smith $e t a l^{3}$ reported that human peripheral blood monocytes/macrophages are spontaneously cytotoxic for G lamblia trophozoites and this cytotoxicity is reduced in chronic giardiasis. ${ }^{4}$ In another study they reported defective spontaneous cytotoxicity but normal antibody dependent cytotoxicity by resident macrophages isolated from $\mathrm{C} 3 \mathrm{H} / \mathrm{Hej}$ mice. ${ }^{5}$

Giardia lamblia has been shown to infect mice. ${ }^{6-8}$ Using a mouse model, we have examined the role of cytotoxic effector cells in resistance of mice to this infection. Direct cytotoxicity of lymphocytes and antibody dependent cell mediated cytotoxicity against $G$ lamblia are likely to be most relevant in mucosae. We have therefore investigated the direct and antibody mediated cytotoxicity of mucosal lymphocytes (intraepithelial lymphocytes and lamina propria lymphocytes) against $G$ lamblia.

\section{Methods}

ANIMALS AND MODE OF INFECTION

Parasite free, 2-3 weeks old Swiss albino mice,

Address for correspondence: Professor R C Mahajan. Head, Department of Parasitology, Postgraduate Institute of Medical Education and Research, Chandigarh-160012, India.

Received for publication 9 April 1985 weighing $10-12 \mathrm{~g}$ were used in this study. G lamblia cysts were obtained from the stool of a patient and a fixed inoculum of 10000 cysts $/ 0 \cdot 2 \mathrm{ml}$ was prepared on a sucrose gradient ${ }^{9}$ and fed to the animals. ${ }^{10}$ Five animals were killed on each of the days $0,10,20$, and 30 postinfection.

QUANTITATION OF CYST AND TROPHOZOITE

(a) Cyst count

Two hour stool samples from each animal were collected, homogenised in normal saline and layered on sucrose gradient. ${ }^{9}$ The results were expressed as number of cysts/g of stool.

\section{(b) Trophozoite count}

The small intestine was flushed with a fixed amount of normal saline, and the trophozoites in the intestinal perfusate counted in a haemocytometer. ${ }^{6}$

\section{PREPARATION OF EFFECTOR CELLS}

(a) Splenic lymphocytes

These were removed and harvested according to the method described earlier. ${ }^{6}$ They were purified by Ficoll-isopaque density gradient.

\section{(b) Intestinal lymphocytes}

Gut lymphocytes were isolated by a modified method of Davies and Parrott ${ }^{11}$ and Taglibue et al. ${ }^{12}$ Briefly, the small intestine was washed with calcium 
and magnesium free Hank's balanced salt solution. The mesentery, adherent connective tissue and fat were removed from the intestine and Peyers patches were dissected. The intestine was opened longitudinally and cut into 1-2 cm long pieces and washed thoroughly in calcium and magnesium free Hank's balanced salt solution. To isolate intraepithelial lymphocytes, gut pieces were incubated at $37^{\circ} \mathrm{C}$ for 15 minutes in calcium and magnesium free Hank's balanced salt solution containing $5 \mathrm{mmol}$ EDTA with constant stirring. This process was repeated three times. The supernatants were pooled, centrifuged, resuspended in RPMI-1640, filtered through glass wool column and washed. Most of the lymphocytes obtained by this method were from the epithelial layer. ${ }^{11}$

For isolation of lymphocytes from the lamina propria, gut pieces were washed with calcium and magnesium free Hank's balanced salt solution and incubated for 20 minutes in $25 \mathrm{ml}$ RPMI-1640 containing $5 \%$ heat inactivated fetal calf serum (RPMI-FCS) and $2 \mathrm{mmol} \mathrm{L-glutamine} \mathrm{with} \mathrm{stirring.}$ These pieces were then incubated in $15 \mathrm{ml}$ RPMIFCS containing $25 \mathrm{U} / \mathrm{ml}$ collagenase (Boehringer, $\mathrm{W}$. Germany) for 15 minutes. The whole procedure was repeated three times. The supernatants were pooled, filtered through a glass wool column and washed in RPMI-FCS.

The lymphocyte rich preparations of intrapethelial lymphocytes and lamina propria lymphocytes were loaded on a percoll density gradient (Pharmacia, Sweden) and the lymphocytes recovered from the $1 \cdot 050 / 1.085 \mathrm{~g} / \mathrm{ml}$ density interface. Their viability was checked by the $0.2 \%$ trypan blue dye exclusion test. The yield of intraepithelial lymphocytes obtained was $0 \cdot 6-2 \cdot 1 \times 10$. $^{7}$

\section{ANTISERUM AGAINST $G$ lamblia}

Antiserum to $G$ lamblia trophozoites was raised in rabbits $^{13}$ and titrated in a cytotoxicity assay. The serum was used at a dilution of 1:3000 in all experiments. At this concentration, the antiserum itself had no giardiacidal activity. Normal rabbit serum was used at the same dilution. Both normal and immune sera were heated at $56^{\circ} \mathrm{C}$ for 30 minutes before use.

\section{CYTOTOXICITY ASSAY}

Giardi lamblia trohozoites were purified by the Feely and Erlandsen ${ }^{14}$ method of sticking them to polystyrene petri dishes, and washed with RPMI1640 containing $25 \mathrm{mM}$ HEPES, $10 \%$ heat inactivated fetal calf serum and $50 \mu \mathrm{g} / \mathrm{ml}$ gentamicin. The cytotoxicity assay was a modified technique of Smith et al. ${ }^{5}$ Trophozoites were labelled with sodium ${ }^{51}$ chromate using $70 \mu \mathrm{Ci} / 5 \times 10^{6}$ parasite $/ \mathrm{ml}$ for $1 \frac{1}{2}$ hours at $37^{\circ} \mathrm{C}$ in a shaking water bath. $0.1 \mathrm{ml}$ of labelled trophozoites $(5 \times 10),{ }^{5}$ suspended in incubation medium, were placed in sterile small test tubes. $0.1 \mathrm{ml}$ of effector cells were also added (effector cell density was adjusted to achieve 25:1, 50:1 and 100:1 $E: T$ ratios). To assay antibody dependent cell mediated cytoxicity, $0.1 \mathrm{ml}$ of immune serum (1:3000 diluted) was added. The effector cells, labelled trophozoites and antiserum were mixed and tubes were centrifuged at $100 \mathrm{~g}$ for five minutes. These were then incubated at $37^{\circ} \mathrm{C}$ in a $5 \% \mathrm{CO}_{2}$ humidified atmosphere for two hours. After incubation, the tubes were centrifuged and the amount of radio-activity in the supernatant was measured in a gamma counter. The maximum release was obtained by treating the labelled trohozoites with $10 \%$ Triton-x100 followed by processing as outlined above. The spontaneous release varied from 10 $15 \%$ of the maximal release. The percentage specific cytotoxicity was calculated by the following formula: $\%$ specific cytotoxicity=experimental release $(\mathrm{cpm})$-spontaneous release $(\mathrm{cpm}) \times 100 /$ maximal release (cpm)-spontaneous release(cpm).

STATISTICAL ANALYSIS

Student's $t$ test was used to analyse all the data.

\section{Results}

Figure 1 shows the kinetics of cyst excretion and trophozoite counts in the intestine during the 30 day period of study. The peak cyst excretion and peak trophozoite count occurred on the 10th postinfection day. By the 30th day, cyst excretion ceased in all the animals, although a few trophozoites could still be detected in $30-40 \%$ of infected animals in the intestinal washings.

Different effector:target cell (E:T) ratios were used $(25: 1,50: 1$ and 100:1) to test for direct cytotoxicity and antibody dependent cell mediated cytoxicity. There was a slight but consistent increase in direct cytotoxicity at E:T ratios of 50:1 and 100:1. A very low level of direct cytotoxicity $(6 \cdot 34 \pm 2.15 \%)$ was observed at $E: T$ ratios of $25: 1$ with splenic lymphocytes, while with intraepithelial lymphocytes and lamina propria lymphocytes, the respective values were $19.03 \pm 2.08 \%$ and $18.30 \pm 3.92 \%$. With lamina propria lymphocytes, the antibody dependent cell mediated cytoxicity was much higher $(44.98 \%)$, in comparison to the values obtained with intraepithelial lymphocytes and splenic lyphocytes at E:T ratios of 100:1 (Fig. 2).

Intraepithelial lymphocytes showed a cytotoxic activity of $20.6 \pm 5.63 \%$ before infection. On the 20th postinfection day, the values were increased to $39.82 \pm 5.87 \%(p<0.01)$, whereas antibody depen- 


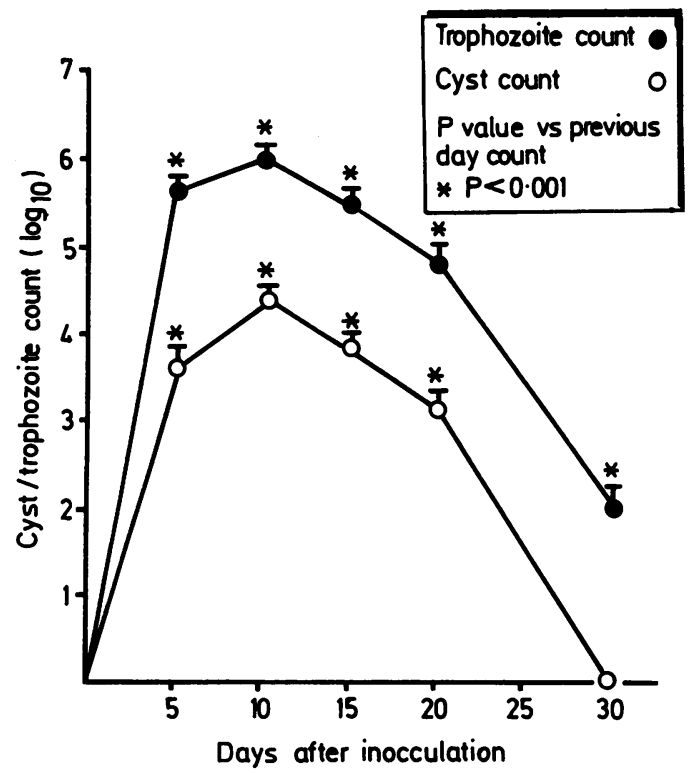

Fig. 1 Giardia lamblia cyst and tropozoite counts $\left(\log _{10}\right)$ on different postinfection days. Each point represents the mean $\pm S D$ of five animals.

dent cell mediated cytoxicity for intraepithelial lymphocytes showed no significant change from the preinfection value. In contrast, lamina propria lymphocytes showed a significantly higher direct cytotoxicity and antibody dependent cell mediated cytoxicity on day 20 and 30 (Table 1 ).

The level of direct cytotoxicity exhibited by splenic lymphocytes at E:T ratios of 50:1 before infection was $12.9 \pm 5.4 \%$; this remained unchanged after infection (Table 2). In the presence of immune serum, cytotoxic activity was augmented to a significant level $(p<0.01$ and $p<0.02$ respectively on 20 th and 30th day).

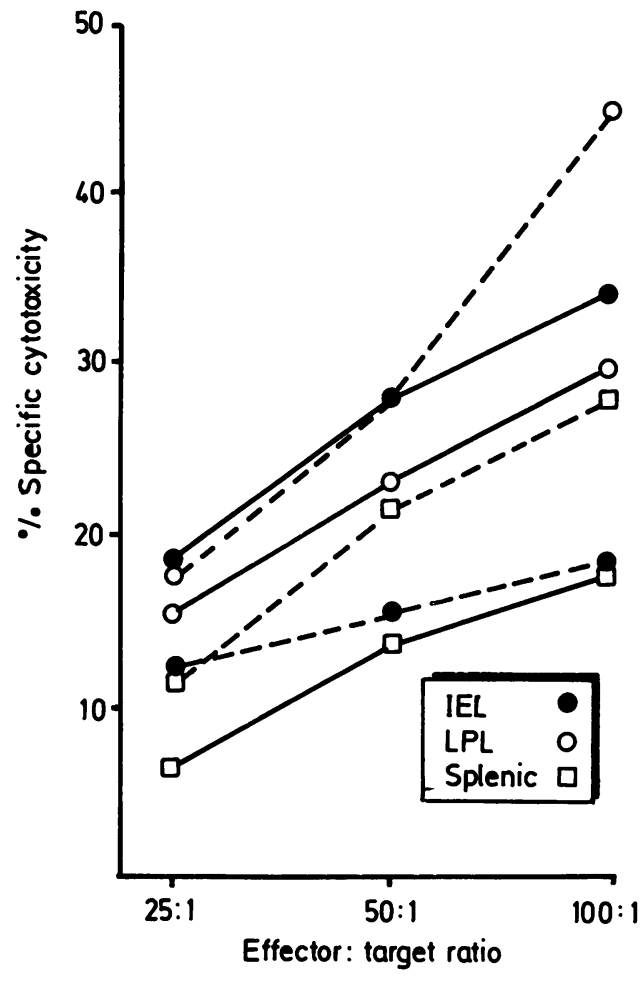

Fig. 2 Direct (continuous line) and antibody dependent (dotted line) cell mediated cytotoxic activity exhibited by splenic ( $\square), I E L(O)$ and $L P L(O)$ at different E:T ratios against $\mathrm{G}$ lamblia trophozoites. Values represent the mean of three experiments before infection.

\section{Discussion}

In our mouse model, $G$ lamblia infection persisted for 30 days. The selfresolution of the infection appears to be immune mediated. We have already

Table 1 Level of cytotoxicity shown by intraepithelial lymphocytes and lamina propria lymphocytes at E:T ratios of 25:1 using radio labelled giardia trophozoites as target cells (Mean $\pm S D)$

\begin{tabular}{|c|c|c|c|c|c|}
\hline \multirow{2}{*}{$\begin{array}{l}\text { Effector } \\
\text { cells }\end{array}$} & & \multicolumn{4}{|c|}{ Postinfection days } \\
\hline & & 0 & 10 & 20 & 30 \\
\hline \multirow[t]{2}{*}{ IEL } & Direct & $20 \cdot 6 \pm 5 \cdot 63$ & $25 \cdot 84 \pm 6 \cdot 42$ & $\begin{array}{l}39 \cdot 82 \pm 5 \cdot 87 \\
(<0 \cdot 01)\end{array}$ & $\begin{array}{l}32 \cdot 01 \pm 5 \cdot 35 \\
(<0 \cdot 05)\end{array}$ \\
\hline & $\mathrm{ADCC}$ & $15 \cdot 11 \pm 5 \cdot 11$ & $19 \cdot 49 \pm 4 \cdot 69$ & $20 \cdot 56 \pm 4 \cdot 09$ & $21 \cdot 9 \pm 9 \cdot 0$ \\
\hline \multirow[t]{2}{*}{ LPL } & Direct & $15 \cdot 75 \pm 4 \cdot 85$ & $22 \cdot 3 \pm 5 \cdot 49$ & $\begin{array}{l}31.92 \pm 7.23 \\
(<0.05)\end{array}$ & $\begin{array}{l}29.02 \pm 7.02 \\
(<0.05)\end{array}$ \\
\hline & $\mathrm{ADCC}$ & $14 \cdot 00 \pm 4 \cdot 83$ & $20 \cdot 10 \pm 6 \cdot 06$ & $\begin{array}{l}38 \cdot 82 \pm 4 \cdot 21 \\
(<0 \cdot 01)\end{array}$ & $\begin{array}{l}33.97 \pm 4.42 \\
(<0.01)\end{array}$ \\
\hline
\end{tabular}

${ }^{*} \mathrm{p}$ value $v s$ day value. 
Table 2 Level of cytotoxicity shown by splenic lymphocytes at $E: T$ ratios of 50:1 using radio labelled $\mathrm{G}$ lamblia trophozoites as target cells

\begin{tabular}{lllll}
\hline \multicolumn{5}{c}{ Postinfection days } \\
\cline { 2 - 5 } & 0 & 10 & 20 & 30 \\
\hline Direct & $12.92 \pm 5.4$ & $18 \cdot 20 \pm 6.60$ & $24.98 \pm 7.2$ & $23.93 \pm 10.42$ \\
ADCC & $21.29 \pm 5.07$ & $28.06 \pm 7.05$ & $\begin{array}{l}43.72 \pm 7.04 \\
(<0.01)\end{array}$ & $\begin{array}{l}37.88 \pm 8.47 \\
(<0.02)\end{array}$ \\
\hline
\end{tabular}

$\mathrm{p}$ values $v s$ day value.

reported the appearance of antibodies in these animals during the course of primary and secondary infection. ${ }^{15} 2$ In this study, we have shown that intraepithelial lymphocytes populations exhibit only direct cytotoxicity, where as lamina propria lymphocytes exhibit both direct and antibody dependent cell mediated cytoxicity. The augmented level of cytotoxicity of these two lymphocyte populations coincides with the decline of parasite numbers in the intestine. Giardia lamblia infection in mice has been shown to increase the intraepithelial lymphocyte count. ${ }^{1617}$ The intraepithelial lymphocytes population is dominated by T cells, ${ }^{18}$ and in $G$ lamblia infected mice they respond by blast transformation with $G$ lamblia antigen. ${ }^{17}$ The presence of cytotoxic $\mathrm{T}$ cells in the intraepithelial lymphocytes and lamina propria lymphocytes population has also been shown. ${ }^{19}$ Owen et $a l^{20}$ showed the attachment of lymphocytes to $G$ muris trophozoites in the lumen, and thus the higher level of direct cytotoxicity exhibited by intraepithelial lymphocytes may be because of their continuous presence in close vicinity to the parasite. Different patterns of cytotoxicity between the two intestinal lymphocyte populations may be explained either by population heterogeneity or by rigorous selection of homogenous population at the basement layer of the epithelium (by the failure of antibody dependent cell mediated cytoxicity to penetrate the epithelium). Alternatively a specialised microenvironment might produce phenotypic changes.

In the human host, Smith et al ${ }^{21}$ have reported that the peripheral blood granulocytes, but not lymphocytes, were cytotoxic for $G$ lamblia. The predominant isotype of the antibodies in antibody dependent cell mediated cytoxicity was IgG, but when IgG depleted serum was used, there was still some cytotoxic acitivity. This raises the possibility that other immunoglobulin isotypes may also mediate antibody dependent cell mediated cytoxicity. In mucosal secretions, secretory IgA is the predominant isotype. It has been recently reported by Taglibue et $a l^{22}$ that S-IgA in mice can mediate antibacterial antibody dependent cell mediated cytoxicity when bound to lymphocytes from gut lymphoid tissue. It is possible that specific S-IgA may be more effective in augmenting antibody dependent cell mediated cytoxicity by lamina propria lymphocytes, or even by intraepithelial lymphocytes, in our system.

No increase in direct cytotoxicity occurred with the splenic lymphocytes but the antibody dependent cell mediated cytoxicity was significantly augmented. Taglibue et al, ${ }^{12}$ in a preliminary study, reported an increase in splenic NK activity when mice were infected with Nippostrongylus brasiliensis or Giardia muris. These workers did not give details of their observations thus making comparisons difficult.

We conclude that intraepithelial lymphocytes exhibit direct cytotoxicity, whereas lamina propria lymphocytes exhibit both direct and antibody dependent cell mediated cytoxicity against $G$ lamblia. In contrast, splenic lymphocytes exhibit only antibody dependent cell mediated cytoxicity. These findings may help in explaining the mechanism of mucosal defence against $G$ lamblia infection.

\section{References}

1 Moore GT, Cross WM, McGuire D, et al. Epidemic giardiasis at a ski resort. $N$ Engl $J$ Med 1969; 281: 402-7.

2 Kanwar SS, Ganguly NK, Mahajan RC, Walia BNS. Acquired resistance to Giardia lamblia infection in mice. Trop Geog Med 1985; 37: 32-6.

3 Smith PD, Elson CO, Keister DB, Nash TE. Human host response to Giardia lamblia infection spontaneous killing by mononuclear leucocytes in vitro. $J$ Immunol 1981; 128: 1372-6.

4 Smith PD, Gillin FD, Spira WM, Nash TE. Chronic giardiasis: studies on drug sensitivity, toxin production and host immune response. Gastroenterology 1982; 83: 797-803.

5 Smith PD, Keister DB, Wahl SM, Meltzer MS. Defective spontaneous but normal antibody dependent cytotoxicity for an extracellular protozoan parasite, Giardia lamblia by $\mathrm{C} 3 \mathrm{H} / \mathrm{Hej}$ mouse macrophages. Cell Immunol 1984; 85: 244-51.

6 Ganguly NK, Vasudeva V, Anand BS, Chandnani RE, Mahajan RC. Study of lymphocyte sub-populations in Giardia infected mice. Ann Trop Med Parasitol 1981; 75: $347-51$

7 Vasudeva V, Ganguly NK, Anand BS, Radhakrishna V, Dilawari JB, Mahajan RC. A study of Giardia infection in irradiated and thymectomised mice. J Trop Med Hyg 1982; 82: 119-24.

8 Hill DR, Guerrant RL, Pearson RD, Hewlett EL. Giardia lamblia infection of sucking mice. J Infect Dis 1983; 147: 217-21. 
9 Olveda RK, Andrews JS, Hewlett EL. Murine giardiasis localization of trophozoites and small bowel histopathology during the course of infection. Am J Trop Med Hyg 1982; 31: 60-6.

10 Roberts Thomson IC, Stevens DP, Mahmoud AAF, Warren KS. Giardiasis in the mouse: an animal model. Gastroenterology 1976; 71: 57-61.

11 Davies MDJ, Parrott DMV. Preparation and purification of lymphocytes from the epithelium and lamina propria of murine small intestine. Gut 1981; 22: 481-8.

12 Taglibue A, Befus AD, Clark DA, Beinenstock J. Characteristics of natural killer cells in the murine intestinal epithelium and lamina propria. J Exp Med 1982; 155: 1785-96.

13 Craft JC, Nelson JD. Diagnosis of giardiasis by counter immunoelectrophoresis of feces. J Infect Dis 1982; 145: 499-504.

14 Feely DE, Erlandsen S. Isolation and purification of giardia trophozoites from rat intestine. J Parasitol 1981; 67: 59-64.

15 Ganguly NK, Mahajan RC, Radhakrishna V, Dilawari JB, Walia BNS. Haemagglutinating antibodies in experimental giardiasis in normal and thymectomised mice. Ind J Med Res 1981; 74: 527-33.

16 McDonald TT, Ferguson A. Small intestinal epithelial cell kinetics and protozoal infection in mice. Gastroenterology 1978;74: 496-500.

17 Kanwar SS, Ganguly NK, Walia BNS, Mahajan RC. Enumeration of small intestinal lymphocyte population in Giardia lamblia infected mice. J Diar Dis Res 1984; 2: 243-8.

18 Guy-Grand D, Gricellic C, Vassalli P. The mouse gut $T$ lymphocyte, a novel type of $T$ cell. Nature, origin and traffic in mice in normal and graft-versus host conditions. J Exp Med 1978; 148: 1661-76.

19 Davies MDJ, Parrott DMV. The early appearance of cytotoxic $\mathrm{T}$ cells in murine gut mucosa. Clin Exp Immunol 1980; 42: 273-79.

20 Owen RL, Nemanic PC, Stevens DP. Ultrastructural observation on giardiasis in a murine model I. Intestinal distribution, attachment and relationship to the immune system of Giardia muris. Gastroenterology 1979; 76: 757-69.

21 Smith PD, Keister DB, Elson CO. Human host response to Giardia lamblia II. Antibody-dependent killing in-vitro. Cell Immunol 1983; 82: 308-15.

22 Taglibue A, Nencioni L, Villa L, Keren DF, Lowell GH, Boraschi D. Antibody dependant cell mediated antibacterial activity of intestinal lymphocytes with secretory IgA. Nature 1983; 306: 184-6. 